\title{
The Differences in Perceptions of Interprofessional Education Among Health Profession Students: The Indonesian Experience
}

This article was published in the following Dove Press journal:

Journal of Multidisciplinary Healthcare

\author{
Dedy Syahrizal $\mathbb{D}^{\prime}$ \\ Teuku Renaldi ${ }^{2}$ \\ Sukma Wulan Dianti ${ }^{3}$ \\ Noraliyatun Jannah (iD) ${ }^{4}$ \\ R Rachmah (iD ${ }^{4}$ \\ Sarah Firdausa ${ }^{5}$ \\ Azizah Vonna (1D ${ }^{6}$ \\ 'Department of Biochemistry, Faculty of \\ Medicine, Universitas Syiah Kuala, Banda \\ Aceh, Aceh, Indonesia; ${ }^{2}$ Department of \\ Public Health, Faculty of Medicine, \\ Universitas Syiah Kuala, Banda Aceh, \\ Aceh, Indonesia; ${ }^{3}$ Bachelor of Medicine \\ Program, Faculty of Medicine, Universitas \\ Syiah Kuala, Banda Aceh, Aceh, Indonesia; \\ ${ }^{4}$ Faculty of Nursing, Universitas Syiah \\ Kuala, Banda Aceh, Aceh, Indonesia; \\ ${ }^{5}$ Department of Internal Medicine, \\ Faculty of Medicine, Universitas Syiah \\ Kuala, Banda Aceh, Aceh, Indonesia; \\ ${ }^{6}$ Department of Pharmacy, Faculty of \\ Mathematics and Natural Sciences, \\ Universitas Syiah Kuala, Banda Aceh, \\ Aceh, Indonesia
}

Purpose: Interprofessional education (IPE) is defined as a practice of collaboration between two or more students from different health profession programs in which the students study with and about, and learn from, each other. IPE is an educational method that trains students to perform in terms of good communication and teamwork which will be useful for the implementation of interprofessional collaboration (IPC) at health-care facilities. The aim of this study is to identify the perceptions of medicine and health profession students on IPE at Universitas Syiah Kuala, Indonesia.

Materials and Methods: This study was conducted in five health profession programs at Universitas Syiah Kuala, Indonesia. Data were collected using a questionnaire which was then distributed to 286 students sampled with a stratified random sampling method. Analyses were conducted by using a univariate statistical analysis to observe students' perceptions of IPE. Students were considered to have a positive perception if their total score was above the median score.

Results: More than half of the students $(51.4 \%)$ in this study had a positive perception toward IPE. However, upon exploration of students' perceptions separately for each study program, only a minority of medical students responded with a positive perception toward IPE (37\%). In contrast, the majority of students from dentistry, psychology, nursing, and pharmacy study programs showed a positive perception of IPE, with the pharmacy study program being the program with the highest proportion of students who showed a positive perception $(62.5 \%, 53.5 \%, 56.4 \%$, and $75 \%$, respectively).

Conclusion: The majority of medical students show a negative perception toward IPE in contrast to students from other health profession programs at Universitas Syiah Kuala. The pharmacy study program shows the highest proportion of students with a positive perception among all other students.

Keywords: medical student, pharmacy student, health profession programs, student positive perception

\section{Introduction}

Healthcare delivery is changing towards having a better quality of service. Among many healthcare delivery quality improvement concepts, the well-known paradigm of patient-centered care is currently advancing. Patient-centered care calls all professionals involved in healthcare delivery to perform good collaboration in teamwork; in other words, interprofessional collaboration (IPC) is an integral part of patient-centered care. However, either partial or total failure of patient-centered
Correspondence: Azizah Vonna

Tel +62 $82163-443508$

Email azizahvonna@unsyiah.ac.id 
care due to failure to properly implement IPC is not uncommon. ${ }^{1}$ One report from the World Health Organization (WHO) shows that the majority (70-80\%) of healthcare service failures were due to poor communication among health-care professionals involved in the service. ${ }^{2}$ In order to improve the quality of IPC, interprofessional education (IPE) is implemented as a training and learning method in health profession programs. ${ }^{3}$

IPE as a training and learning method was introduced in the US in the 1940s, in Canada in the 1960s, in Sweden and Australia in the 1970s, and in the UK in the 1980s. ${ }^{4}$ The WHO was the first international organization to propose IPE as a strategy to yield good collaboration between different health-care professionals in order to holistically solve patients' problems and deliver a good quality of healthcare service. ${ }^{2}$ Many other organizations, including the National Academies of Practice and the American Public Health Association support the implementation of IPE in health profession higher education programs. ${ }^{5}$

Interprofessional education (IPE) is a training and learning method in which two or more students from different health profession program study with and about, and learn from, each other. ${ }^{2,5,6}$ The main objective of IPE is to make the students ready to collaborate with professionals from different health professions in a teamwork delivering the highest quality of healthcare service. The exposure to IPE will hopefully make students more ready for IPC. The readiness encompasses knowledge, skills, attitude, and good practice of communication. ${ }^{5,6,8,9}$ As a training and learning method, IPE has several characteristics as follows: ${ }^{7}$ (1) Students understand the basic concepts, principles and contributions of each profession involved; (2) Students are familiarized with the terminology and logics of each profession involved; (3) Students master knowledge and skills from their own profession; (4) Students master the concepts of collaboration.

It is noteworthy to take into account that not all collaboration is IPE. The following points characterize the collaborations that are not IPE: ${ }^{5}$ (1) Students from different health profession programs study the same subject at the same place and time without interacting with each other; (2) Teachers from a health profession education program teach a subject at a different program without elaborating on teaching of IPE and IPC; (3) Students from different health profession programs learn together in a clinical setting, and the learning group is led by student(s) from only one profession without any clear sharing of decision-making and responsibilities. IPE as a learning method that requires the students to master specific IPE-related competency in order to be able to successfully learn in the IPE setting. The competencies are role and responsibility, collaboration and teamwork, effective communication, plus values and ethics. ${ }^{10,11}$

Several universities in Indonesia have been implementing IPE, and most of them are located on the island of Java. Universitas Indonesia (UI), Universitas Gadjah Mada (UGM), Universitas Muhammadiyah Yogyakarta (UMY), Universitas Padjajaran (Unpad) and Universitas Islam Indonesia (UII) are among the Indonesian universities that are implementing IPE. However, IPE is not yet a common practice at most Indonesian universities located on the island of Sumatera, one of which is Universitas Syiah Kuala. Recent development shows an interest in IPE among faculties and leaders at Universitas Syiah Kuala. In accordance with the development, this study was aimed at measuring students' readiness for IPE by identifying the students' perceptions toward upcoming IPE implementation in health profession programs at Universitas Syiah Kuala.

\section{Materials and Methods Study Design}

Our study was an analytic cross-sectional survey study conducted from September to October 2019 at the Universitas Syiah Kuala, Aceh, Indonesia, involving 286 students as respondents in aiming to identify the perceptions of health profession students regarding IPE. All respondents are students from all health profession study programs at Universitas Syiah Kuala and they were in their 3rd and 4th years of the following health profession programs: Bachelor of Medicine, Faculty of Medicine; Bachelor of Psychology, Faculty of Medicine; Bachelor of Dentistry, Faculty of Dentistry; Bachelor of Nursing, Faculty of Nursing; Bachelor of Pharmacy, Faculty of Mathematics and Natural Sciences.

\section{Sample Size}

The total population of 3rd- and 4th-year health profession program students was 798. In order to produce proportions relevant for each study program, the population of students in each study program was calculated. This then resulted in the proportions of Medical, Psychology, Nursing, Pharmacy and Dental students of $37 \%, 10 \%, 28.6 \%, 10 \%$ and $14.4 \%$, respectively. The study had a time constraint as it coincided with the end of the semester in which the majority of students were undertaking their own final research project and Community Service Program. These programs are held by 
the University and are mandatory for students in the 3rd and 4 th years. Therefore, the sampling was carried out in order to deal with this time constraint. The sample size was calculated using Slovin's Formula, which is used to determine the sample size of the research in which the total population is under $1000 .^{18,19}$

The formula is:

$$
n=\frac{N}{\left(1+N e^{2}\right)}
$$

where $N$ is the population size and $e$ is the margin of error.

Thus, based on our total population of 798 students and the margin of error of 5\%, the sample size of 266 students was generated as the minimum sample size and based on this and the ratio of students within each study program, the numbers of 111, 28, 78, 29 and 40 for Medical, Psychology, Nursing, Pharmacy and Dental students were identified in this study, respectively.

\section{Participant Recruitment}

Third- and fourth-year students from all five study programs were invited to participate in the study and they were gathered at different times. The students were given a brief explanation of the purpose of the study and instructions for filling out the questionnaire. Students who were present and were willing to participate in the study were then given a questionnaire URL link that was accessed through the Google Sheets (spreadsheet) application.

\section{Data Collection}

The data were collected by using a questionnaire developed by the present authors based on several examples in the body of literature regarding IPE competencies and questionnaires from other studies similar to the present study. ${ }^{2,5-7}$ The validity of the questionnaire was reviewed in two stages. First, the questionnaire was evaluated by a panel of health profession education experts including faculty members. After being declared as valid by the panel of experts, the questionnaire was assessed for validity using the Spearman rank correlation coefficient rho, which resulted in the probability value $\mathrm{p}>$ 0.05 . The reliability of the questionnaire was tested using Cronbach's alpha which resulted in the reliability coefficients in the range $0.892-0.898$ indicating the high reliability of the questionnaire and its items.

The questionnaire was written in the Indonesian language and consists of two parts. Part one of the questionnaire collected the following demographic information of the participants: gender, faculty, study program, and study year. Part two of the questionnaire is composed of 27 statements to measure the students' perceptions regarding IPE. These statements were grouped into four categories describing IPE competencies; role and responsibility (statement 1-6), collaboration and teamwork (statement 7-16), effective communication (statement 17-21), and values and ethics (statement 22-27). ${ }^{10,11}$ All statements were assessed on a 5-point Likert scale, ranging from "strongly disagree" (score of 1) to "strongly agree" (score of 5); thus, the minimum score for all statements was 27 and the maximum score was $135 .^{20}$ Participants could respond to each statement by clicking on the scale that best described their opinion.

The questionnaires were distributed and filled online by the participants. The first part of the questionnaire was the informed consent to be completed by the participants. In the informed consent, the present authors briefly described the research project objectives and how the participants could respond to the study questionnaire. The researchers also assured the participants that participation in the study had no risk and was completely voluntary and the participants could withdraw from the study at any time. The participants were also assured that if they withdrew from the study, it would not affect their study pathway in any way. The participants were assured that their personal information and their answers to the questions will be kept totally confidential and will be coded for analysis. After providing their consent, the participants could then continue to the second part which contains demographic data and statements related to students' perceptions of IPE.

\section{Data Analysis}

Data analysis was carried out in two stages. First, univariate statistical analysis was conducted in order to yield the perception scores of each study program. General perception scores from all five study program students were obtained by adding up the scores from all statements. The score was then sorted to yield a median value which was used as the cut-off point to determine positive and negative perceptions. Each perception of each IPE competency was also scored and added up, followed by the calculation of the median value for each competency.

Each statement was also analyzed, by calculating the average score of the Likert scale of students in each study program. The level of significance was considered to be $95 \%$ and p-value $<0.05$. Kruskal-Wallis test was also performed to observe the differences in responses from each student of the study program for each statement. 


\section{Ethical Consideration}

The study has been approved by the Health Research Ethics Committee of the Faculty of Medicine at Universitas Syiah Kuala and the Dr. Zainoel Abidin General Hospital (RSUZA), Banda Aceh (KEPPKN Registration number: 1171012P; No.48/EA/FK-RSUDZA/2019). The questionnaire has been examined and ethically approved by the Ethical Committee which also ensured that the questionnaire did not have any conflict with the interests of the participants. Oral and written explanation regarding the aims and the processes of data collection were provided to participants before they consent to take part in this study.

\section{Results}

\section{Student Demographics}

Our study was able to collect data from 286 students, consisting of 111 Medical students, 28 Psychology students, 78 Nursing students, 29 Pharmacy students and 40 Dental students. The study results show that female students were more dominant than male students $(87.4 \%$ and $12.6 \%$, respectively). In accordance with the student proportions in the five health profession study programs, Medical students took up the largest proportion of this study (38.8\%), followed by Nursing (27.3\%), Dental (14\%), Pharmacy (10.1\%) and Psychology students (9.8\%). More than one half of the respondents $(52.1 \%)$ were 3 rd-year students and the remaining $(47.9 \%)$ were 4 th-year students.

\section{Student Perceptions Regarding IPE}

From 286 students, the sum of each statement gives the result of 85 as the lowest value and 125 as the highest value and the result of 111 as the median value. Thus, from all students, we found that $51.4 \%$ had a positive general perception of IPE and $48.6 \%$ had a negative general perception of IPE. However, upon the exploration of students' perceptions from each study program, it was identified that only a minority of Medical students responded with a positive perception towards IPE (41 (37\%)). In contrast, the majority of students from the Dentistry, Psychology, Nursing, and Pharmacy study programs showed a positive perception of IPE, where the Pharmacy students were those students having the highest positive perception towards the IPE concept $(62.5 \%, 53.5 \%, 56.4 \%$ and $75 \%$, respectively) (Table 1).

Upon exploration separately for each IPE competency, it appears that most students have positive perceptions for each IPE competency, namely, role and responsibility, collaboration and teamwork, effective communication, and values and ethics (Table 2). As was identified from the general perception score for each study program, the exploration of the competency-based perception score identified a majority of Medical students who had a negative perception of all four competencies of IPE (Table 3). In addition, most Medical students have negative perceptions of teamwork and collaboration with other

Table I Students' Perceptions of IPE

\begin{tabular}{|l|l|l|l|l|l|}
\hline \multirow{2}{*}{ Study Program } & \multicolumn{2}{|l|}{ Score } & \multicolumn{2}{l|}{ Students' Perceptions (n(\%)) } \\
\cline { 2 - 6 } & Minimum & Maximum & Median & Positive & Negative \\
\hline Dentistry & 97 & 122 & 112.5 & $25(62.5)$ & $15(37.5)$ \\
Psychology & 99 & 123 & 112.5 & $15(53.5)$ & $13(46.5)$ \\
Nursing & 97 & 124 & 112 & $44(56.4)$ & $34(43.6)$ \\
Pharmacy & 100 & 122 & 113 & $22(75.8)$ & $7(24.2)$ \\
Medicine & 85 & 125 & 105 & $41(37)$ & $70(63)$ \\
\hline
\end{tabular}

Abbreviation: IPE, interprofessional education.

Table 2 Students' Perceptions for Each Competency of IPE

\begin{tabular}{|l|l|l|l|l|l|}
\hline \multirow{2}{*}{ IPE Competencies } & \multicolumn{2}{l}{ Score } & \multicolumn{2}{l|}{ Student's Perceptions (n(\%)) } \\
\cline { 2 - 6 } & Minimum & Maximum & Median & Positive & Negative \\
\hline Role and responsibility & 15 & 28 & 22 & $163(57)$ & $123(43)$ \\
Collaboration and teamwork & 32 & 50 & 43 & $153(53.5)$ & $133(46.5)$ \\
Effective communication & 13 & 25 & 19 & $164(57.3)$ & $122(42.7)$ \\
Values and ethics & 18 & 30 & 27 & $157(54.9)$ & $129(45)$ \\
\hline
\end{tabular}

Abbreviation: IPE, interprofessional education. 
Table 3 From Each Study Program - Students' Perceptions of Four Competencies of IPE

\begin{tabular}{|c|c|c|c|c|c|c|c|c|c|c|}
\hline \multirow[t]{3}{*}{ IPE Competencies } & \multicolumn{10}{|c|}{ Student's Perceptions (\%) } \\
\hline & \multicolumn{2}{|c|}{ Dentistry } & \multicolumn{2}{|c|}{ Psychology } & \multicolumn{2}{|c|}{ Nursing } & \multicolumn{2}{|c|}{ Pharmacy } & \multicolumn{2}{|c|}{ Medicine } \\
\hline & tve & $-\mathbf{v e}$ & +ve & $-\mathbf{v e}$ & tve & $-\mathbf{v e}$ & +ve & -ve & +ve & -ve \\
\hline Role and responsibility & 52.5 & 47.5 & 64.2 & 35.8 & 73 & 27 & 75.8 & 24.2 & 45 & 55 \\
\hline Collaboration and teamwork & 65 & 35 & 50 & 50 & 60.2 & 39.8 & 75.8 & 24.2 & 40.5 & 59.5 \\
\hline Effective communication & 62.5 & 37.5 & 53.6 & 46.4 & 62.8 & 37.2 & 72.4 & 27.6 & 48.6 & 51.4 \\
\hline Values and ethics & 60 & 40 & 60.7 & 39.3 & 61.5 & 38.5 & 62 & 38 & 45 & 55 \\
\hline
\end{tabular}

Abbreviations: IPE, interprofessional education; +ve, positive; -ve, negative.

health professions (59.5\%). Among the students who had a positive perception, Pharmacy students had the highest number with a positive perception of IPE in all four competencies. When compared among the four IPE competencies, there were more students from the Nursing, Dentistry and Pharmacy study programs who showed positive perceptions for role and responsibility competencies (73\%, 64.2\% and 75\%, respectively). These results are very different from those shown by Medical and Dental students, where only about $55 \%$ and $52.5 \%$, respectively, showed a positive perception of role and responsibility.

Perception scores obtained from students of five health profession programs at Universitas Syiah Kuala were generally high for each statement, which shows that they did either agree or strongly agree on the statement representing the IPE concept (Table 4). However, among all statements, four yielded mean scores lower than 3: statement number 2 , number 3 , number 11 , and number 18 and the low score was not different across the students from all health study programs ( $p>0.005)$. In detail, the students from all health profession programs showed their disagreement regarding 1) the need for learning in the same classroom, 2) the need for having a lecturer from a different profession, 3) the need for a group leader who does not function in distributing the roles, and 4) the need for a non-face-to-face communication in IPE.

\section{Discussion}

Our study involved more Medical students compared to students from other health programs, this is consistent with a comparison of the number of students and represents the general student population. In Indonesia, the profession of a doctor is still in great demand and is the first choice for students who want to become health practitioners.

Perceptions of IPE obtained from five health profession study programs at Universitas Syiah Kuala were generally positive. Among all programs, the majority of Medical students showed a negative perception regarding IPE in contrast to Dental, Psychology, Nursing and Pharmacy students. The presumed interprofessional hierarchy might be the main underlying factor that led to this finding. Traditionally, doctors tend to believe in the interprofessional hierarchy in which doctors are at the top position. This belief is transferred to Medical students through the teaching process. ${ }^{5}$ This finding - which reveals an underlying belief in the professional hierarchy - can be perceived as a potential inhibitor for the implementation of IPE. However, in considering IPC as a patient-centered healthcare quality improvement model that negates professional hierarchy, it is better to perceive this finding as a justification for the immediate implementation of IPE at Universitas Syiah Kuala. This justification is in line with recommendations from previous studies. ${ }^{12,13}$

Generally, positive perceptions of the four competencies of IPE were high among Dental, Psychology, Nursing and Pharmacy students, with Pharmacy students showing the highest student number with respect to positive perception. Our results show a similarity with the findings of previous studies, which reported that students of Pharmacy program show a more positive response towards IPE compared to other health study program students. ${ }^{14,21,22}$ On the other hand, there were more Medical students who had a negative perception. This finding suggests the need for immediate implementation of IPE at Universitas Syiah Kuala as a strategy to resolve the misunderstanding.

Perceptions of IPE-related effective communication competency obtained from health profession programs at Universitas Syiah Kuala are generally positive. However, Medical students' scores are significantly lower than those of Nursing, Dental and Pharmacy students. This finding is in line with the mean scores obtained from questionnaire statements Number 2 and Number 18 (the need for learning in the same classroom and the need for a non-face-to-face communication in IPE). This finding is similar to the result of a review of 21 
Table 4 Mean Scores for Each of the Statements Regarding IPE Perception

\begin{tabular}{|c|c|c|c|c|c|c|c|}
\hline \multirow[t]{2}{*}{ No } & \multirow[t]{2}{*}{ Statements } & $\begin{array}{l}\text { Dentistry } \\
n=111\end{array}$ & $\begin{array}{l}\text { Psychology } \\
n=28\end{array}$ & $\begin{array}{l}\text { Nursing } \\
n=78\end{array}$ & $\begin{array}{l}\text { Pharmacy } \\
n=29\end{array}$ & $\begin{array}{l}\text { Medical } n= \\
\text { III }\end{array}$ & \multirow[t]{2}{*}{ p-value } \\
\hline & & Mean \pm SD & Mean \pm SD & Mean \pm SD & Mean \pm SD & Mean \pm SD & \\
\hline \multicolumn{8}{|c|}{ Role and Responsibility } \\
\hline I. & $\begin{array}{l}\text { In IPE, students from different health profession programs have } \\
\text { equivalent academic roles. }\end{array}$ & $4.39 \pm 0.88$ & $4.50 \pm 0.69$ & $4.39 \pm 0.67$ & $4.55 \pm 0.63$ & $4.55 \pm 0,63$ & 0.001 \\
\hline 2. & $\begin{array}{l}\text { Students from different health profession programs can learn in } \\
\text { the same classroom by interacting with each other. }\end{array}$ & $3.02 \pm 1.09$ & $2.17 \pm 1.15$ & $2.41 \pm 1.25$ & $2.34 \pm 1.17$ & $2.34 \pm 1.17$ & 0.011 \\
\hline 3. & $\begin{array}{l}\text { In IPE, a teacher can teach in different faculties (for example: } \\
\text { bachelor of pharmacy teacher can teach in the faculty of } \\
\text { medicine). }\end{array}$ & $2.02 \pm 0.86$ & $2.14 \pm 1.07$ & $2.12 \pm 0.9$ & $1.79 \pm 1.04$ & $2.05 \pm 0.94$ & 0.564 \\
\hline 4. & In IPE, students have to share roles in solving the given problem. & $4.2 \pm 0.64$ & $4.46 \pm 0.57$ & $4.46 \pm 0.59$ & $4.55 \pm 0.5$ & $4.3 \pm 0.61$ & 0.059 \\
\hline 5. & $\begin{array}{l}\text { In the learning process, students are required to have knowledge } \\
\text { on the role and responsibility of every group member. }\end{array}$ & $4.4 \pm 0,63$ & $4.57 \pm 0.57$ & $4.6 \pm 0.49$ & $4.7 \pm 0.43$ & $4.4 \pm 0.59$ & 0.009 \\
\hline 6. & Interprofessional hierarchy is not recognized in IPE. & $3.9 \pm 1.04$ & $4.21 \pm 0.83$ & $4.35 \pm 0.77$ & $4.65 \pm 0.61$ & $3.8 \pm 0.97$ & 0.00 \\
\hline \multicolumn{8}{|c|}{ Collaboration and Teamwork } \\
\hline 7. & $\begin{array}{l}\text { In IPE, students learn to play roles in an interprofessional team } \\
\text { focusing on patient management. }\end{array}$ & $4.45 \pm 0.71$ & $4.39 \pm 0.87$ & $4.44 \pm 0.67$ & $4.58 \pm 0.62$ & $4.3 \pm 0.62$ & 0.303 \\
\hline 8. & $\begin{array}{l}\text { In IPE, every student knows their own job and their friends' jobs } \\
\text { within the teamwork. }\end{array}$ & $4.67 \pm 0.47$ & $4.39 \pm 0.56$ & $4.56 \pm 0.52$ & $4.55 \pm 0.57$ & $4.27 \pm 0.65$ & 0.001 \\
\hline 9. & $\begin{array}{l}\text { In IPE, the sharing of roles is determined by the competencies } \\
\text { expected from each profession. }\end{array}$ & $4.32 \pm 0.61$ & $4.21 \pm 0.68$ & $4.32 \pm 0.78$ & $4.44 \pm 0.68$ & $4.17 \pm 0.78$ & 0.363 \\
\hline 10. & In IPE, every team member can be a team leader. & $4.47 \pm 0.75$ & $4.14 \pm 0.84$ & $4.39 \pm 0.7$ & $4.2 \pm 0.99$ & $3.82 \pm 0.98$ & 0.00 \\
\hline 11. & In IPE, roles are not distributed by group leader. & $1.85 \pm 0.83$ & $2.6 \pm 1.19$ & 2. $08 \pm 0.9$ & $2.03 \pm 0.98$ & $2.15 \pm 1.03$ & 0.039 \\
\hline 12. & Decision making has to involve all group members. & $4.57 \pm 0.59$ & $4.57 \pm 0.63$ & $4.73 \pm 0.47$ & $4.82 \pm 0.38$ & $4.44 \pm 0.69$ & 0.004 \\
\hline 13. & $\begin{array}{l}\text { Every group member exercises ethics in communicating with } \\
\text { other group members. }\end{array}$ & $4.77 \pm 0.42$ & $4.64 \pm 0.48$ & $4.7 \pm 0.45$ & $4.75 \pm 0.43$ & $4.6 I \pm 0.5$ & 0.288 \\
\hline 14. & $\begin{array}{l}\text { In IPE, decisions are made collectively and by involving the specific } \\
\text { competencies of each group member. }\end{array}$ & $4.62 \pm 0.49$ & $4.53 \pm 0.57$ & $4.64 \pm 0.53$ & $4.58 \pm 0.5$ & $4.36 \pm 0.65$ & 0.01 \\
\hline 15. & Collaboration between group members is essential in IPE. & $4.77 \pm 0.42$ & $4.6 \pm 0.49$ & $4.7 \pm 0.48$ & $4.86 \pm 0.35$ & $4.54 \pm 0.55$ & 0.007 \\
\hline 16. & $\begin{array}{l}\text { In a clinical setting, students will be taught by a professional } \\
\text { (Doctor, Nurse, and Pharmacist) with role sharing for decision } \\
\text { making and responsibility in patient management. }\end{array}$ & $4.6 \pm 0.59$ & $4.32 \pm 0.61$ & $4.58 \pm 0.52$ & $4.68 \pm 0.66$ & $4.36 \pm 0.59$ & 0.006 \\
\hline \multicolumn{8}{|c|}{ Effective Communication } \\
\hline 17. & A specific communication method is needed in IPE. & $4.15 \pm 0.76$ & $3.85 \pm 0.75$ & $4.17 \pm 0.73$ & $4.31 \pm 0.66$ & $4.03 \pm 0.85$ & 0.168 \\
\hline 18. & Non-face-to-face communication can be carried out in IPE. & $1.97 \pm 0.76$ & $2.32 \pm 1.09$ & $1.8 \pm 0.75$ & $1.62 \pm 0.72$ & $2.04 \pm 0.92$ & 0.013 \\
\hline 19. & $\begin{array}{l}\text { Communication in IPE has to be consistent with direct references } \\
\text { to a given problem. }\end{array}$ & $4.47 \pm 0.59$ & $4.25 \pm 0.64$ & $4.43 \pm 0.59$ & $4.62 \pm 0.49$ & $4.2 \pm 0.62$ & 0.011 \\
\hline 20. & $\begin{array}{l}\text { Presumed interprofessional hierarchy may never inhibit } \\
\text { communication in IPE. }\end{array}$ & $4.32 \pm 0.85$ & $4.42 \pm 0.57$ & $4.48 \pm 0.59$ & $4.65 \pm 0.61$ & $4.14 \pm 0.8$ & 0.002 \\
\hline 21. & $\begin{array}{l}\text { The utility of communication media in IPE has to be based on } \\
\text { regulations. }\end{array}$ & $4.32 \pm 0.85$ & $4.42 \pm 0.57$ & $4.48 \pm 0.59$ & $4.65 \pm 0.61$ & $4.14 \pm 0.8$ & 0.028 \\
\hline
\end{tabular}

(Continued) 
Table 4 (Continued).

\begin{tabular}{|c|c|c|c|c|c|c|c|}
\hline \multirow[t]{2}{*}{ No } & \multirow[t]{2}{*}{ Statements } & $\begin{array}{l}\text { Dentistry } \\
\mathrm{n}=111\end{array}$ & $\begin{array}{l}\text { Psychology } \\
n=28\end{array}$ & $\begin{array}{l}\text { Nursing } \\
n=78\end{array}$ & $\begin{array}{l}\text { Pharmacy } \\
n=29\end{array}$ & $\begin{array}{l}\text { Medical } n= \\
\text { III }\end{array}$ & \multirow[t]{2}{*}{ p-value } \\
\hline & & Mean \pm SD & Mean \pm SD & Mean \pm SD & Mean \pm SD & Mean \pm SD & \\
\hline \multicolumn{8}{|c|}{ Values and Ethics } \\
\hline 22 & $\begin{array}{l}\text { An interprofessional relationship is needed in an educational } \\
\text { process in health profession programs. }\end{array}$ & $4.52 \pm 0.64$ & $4.5 \pm 0.57$ & $4.62 \pm 0.53$ & $4.51 \pm 0.68$ & $4.28 \pm 0.73$ & 0.01 \\
\hline 23. & $\begin{array}{l}\text { In IPE, each group member has a specific knowledge and specific } \\
\text { skills. }\end{array}$ & $4.1 \pm 0.59$ & $4.39 \pm 0.68$ & $4.32 \pm 0.61$ & $4.17 \pm 0.92$ & $4.16 \pm 0.69$ & 0.235 \\
\hline 24. & $\begin{array}{l}\text { In IPE, students can develop their already-acquired knowledge, } \\
\text { attitude and skills. }\end{array}$ & $4.52 \pm 0.59$ & $4.6 \pm 0.49$ & $4.5 \pm 0.52$ & $4.62 \pm 0.49$ & $4.44 \pm 0.56$ & 0.433 \\
\hline 25. & $\begin{array}{l}\text { IPE improves competencies and confidence in interprofessional } \\
\text { interactions. }\end{array}$ & $4.47 \pm 0.64$ & $4.6 \pm 0.49$ & $4.56 \pm 0.49$ & $4.62 \pm 0.67$ & $4.36 \pm 0.64$ & 0.088 \\
\hline 26. & IPE develops trust and respect between professions. & $4.55 \pm 0,63$ & $4.57 \pm 0.63$ & $4.63 \pm 0,51$ & $4.75 \pm 0.57$ & $4.4 I \pm 0.61$ & 0.03 \\
\hline 27. & $\begin{array}{l}\text { Implementation of IPE can improve healthcare quality and } \\
\text { especially in terms of patient safety. }\end{array}$ & $4.55 \pm 0.59$ & $4.6 \pm 0.49$ & $4.7 \pm 0.45$ & $4.72 \pm 0.52$ & $4.43 \pm 0.64$ & 0.011 \\
\hline
\end{tabular}

Abbreviations: IPE, interprofessional education; SD, standard deviation.

articles in the literature on Medical education conducted in 2017 which reveals that Medical education settings force the student to only communicate with their fellow Medical students, and this situation leads to poor communication with students from other health profession programs. ${ }^{16}$ Similar to the finding from collaboration and teamwork competency scores, this finding from effective communication scores suggests the need for immediate implementation of IPE in order to prepare the students with proper effective communication skills required for IPC. ${ }^{15}$

The majority of students seemed reluctant to study together in one class. A similar result was previously reported for Medical students, in which they felt uncomfortable to study with other health program students. ${ }^{23}$ However, our study shows that this feeling was also experienced by students from other health programs. This can be explained because of the bonding factor that has existed between students, mainly because this study involved students at the final level (third and fourth years), so they already felt comfortable with their own friends and were not too interested in the idea of other students joining in their class.

The students were also not too keen on having lecturers from different professions. This can be caused by students assuming that lecturers from other professions will not be able to transfer the knowledge they need compared to lecturers who are their own peers.

Our study finding also suggested that most students in each health profession program believed that the role in a collaborative team needs to be distributed by the team leader. This is very contrary to the concept of IPE, which states that the role of team leaders in IPE is no longer on dividing roles, but on the coordination function and ensuring that continuous and consistent collaboration can be carried out properly. ${ }^{24}$ Every profession should understand its role in the collaboration team; therefore, they should act and contribute according to that role.

One of the concepts of interprofessional education is regarding communication, which can occur in direct or indirect manner. ${ }^{25}$ However, most students in this study appear to disagree if communication between health practitioners is carried out indirectly. This might be because they do not understand that there are ways of indirect communication that also supports health services and collaboration between professions such as written progress notes on medical records and medication prescription ordered by a physician to a pharmacist.

Perceptions of IPE-related values and ethics competency obtained from health profession programs at Universitas Syiah Kuala are generally positive. However, Medical students' scores are significantly lower than those of Nursing and Dental students. The significant difference was caused by different values and ethics believed in each of the programs. ${ }^{17}$ It is, therefore, the role of IPE to bridge the differences and pave a clear path for IPC.

\section{Conclusion}

It can be concluded from the present study that health profession program students' perceptions of IPE are generally 
positive. However, significant differences are found among the programs both for total perception scores and for individual IPE-related competency perception scores. Among all programs, Medical students possessed the lowest scores. This study recommends the immediate implementation of IPE as a strategy to properly implement IPC.

\section{Acknowledgments}

The authors would like to acknowledge Universitas Syiah Kuala for providing the study grant through Hibah Penelitian Unggulan, Universitas Syiah Kuala, Deans of Faculty of Medicine, Faculty of Nursing, Faculty of Dentistry and Faculty of Mathematics and Natural Sciences of Universitas Syiah Kuala.

Dedy Syahrizal, Teuku Renaldi, Noraliyatun Jannah, R Rachmah, Sarah Firdausa, and Azizah Vonna are currently affiliated with the the recently established Collaboration in Health Science Study Center, Universitas Syiah Kuala, Banda Aceh, Aceh, Indonesia.

\section{Disclosure}

The authors report no conflicts of interest regarding this research.

\section{References}

1. Ebert L, Hoffman K, Levett-jones T, Gilligan C. "They have no idea of what we do or what we know": Australian graduates' perceptions of working in a health care team. Nurse Educ Pract. 2014;14(5):544-550. doi:10.1016/j.nepr.2014.06.005

2. World Health Organization. Human Resources for Health Framework for Action on Interprofessional Education \& Collaborative Practice. Jenewa: World Health Organization (WHO); 2010.

3. Ilmanita D, Rokhman MR. The role of interprofessional education against perception of pharmacist involvement in collaboration between professions. J Manaj Pelayanan Farm. 2014;4(September):166-174.

4. Thistlethwaite JE. Interprofessional education: implications and development for medical education. Educ Med. 2015;16(1):68-73. doi:10.1016/j.edumed.2015.04.007

5. Buring SM, Bhushan A, Broeseker A, et al. Interprofessional education: definitions, student competencies, and guidelines for implementation. $\mathrm{Am}$ J Pharm Educ. 2009;73(4):59. doi:10.5688/aj730459

6. Freeth D, Hammick M, Barr H, Reeves S, Koppel I. Effective Interprofessional Education. Pondicherry: Blackwell Publishing Ltd; 2005.

Journal of Multidisciplinary Healthcare

\section{Publish your work in this journal}

The Journal of Multidisciplinary Healthcare is an international, peerreviewed open-access journal that aims to represent and publish research in healthcare areas delivered by practitioners of different disciplines. This includes studies and reviews conducted by multidisciplinary teams as well as research which evaluates the results or conduct of such teams or healthcare processes in general. The journal

Submit your manuscript here: https://www.dovepress.com/journal-of-inflammation-research-journal
7. Hammick M, Freeth D, Koppel I, Reeves S, Barr H. A best evidence systematic review of interprofessional education: BEME guide no. 9. Med Teach. 2007;44(9):735-751. doi:10.1080/01421590701682576

8. CFHC-IPE. Buku Acuan Umum CFHC-IPE. Yogyakarta: Universitas Gadjah Mada; 2014.

9. Reeves S, Goldman J, Oandasan I. Key factors in planning and implementing interprofessional education in health care settings. J Allied Health. 2007;36(4):231-235.

10. Thistlethwaite JE, Moran M. Learning outcomes for interprofessional education (IPE): literature review and synthesis. J Interprof Care. 2010;24:503-513. doi:10.3109/13561820.2010.483366

11. Panel IECE. Core Competencies for Interprofessional Collaborative Practice: Report of an Expert Panel. Washington DC: Interprofessional Education Collaborative; 2011.

12. Tyastuti D, Onishi H, Ekayanti F, Kitamura K. An educational intervention of interprofessional learning in community based health care in Indonesia: what did we learn from the pilot study? J Educ Pract. 2013;4(25):1-11.

13. OHSU Interprofessional Inittiative. Interprofessional Education. Portland: Oregon Health and Science University; 2014.

14. Rokhman MR, Utami KN, Dianastuti NA. Barrier, Facilitator, and Pharmacist Attitude Modeling to Implement Pharmaceutical Care in the Yogyakarta Regional Community Pharmacy. Universitas Gadjah Mada; 2012.

15. Sundari S. Perception of Professional Stage Students at FKIK UMY About Interprofessional Education at Asri Medical Center Yogyakarta. Medical Education; 2013.

16. Liaison Committe on Medical Education. Functions and Structure of Medical School. Washington DC: Liaison Committe on Medical Education (LCME); 2018.

17. Soemantri D, Sari SP, Ayubi D. Health Collaboration and Teamwork. Jakarta: Rumpun Ilmu Kesehatan Universitas Indonesia; 2019.

18. Almeda J, Capistrano T, Sarte G. Elementary Statistics. Quezon City: UP Press; 2010.

19. Tejada JJ, Punzalan JRB. On the misuse of Slovin's formula. Philippine Statistician. 2012;61(1):129-136.

20. Barua A. Methods for decision-making in survey questionnaires based on Likert scale. Asian J Sci Res. 2013;3(1):35-38.

21. Soriano GP. Readiness of health science students towards interprofessional learning. Int J Nurs Educ. 2019;11(3):74-79. doi:10.5958/ 0974-9357.2019.00068.0

22. El-Awaisi A, Saffouh El Hajj M, Joseph S, Diack L. Perspectives of pharmacy students in Qatar toward interprofessional education and collaborative practice: a mixed methods study. J Interprof Care. 2018;32(6):674-688. doi:10.1080/13561820.2018.1498466

23. Lestari E, Stalmeijer RE, Widyandana D, Scherpbier A. Understanding students' readiness for interprofessional learning in an Asian context: a mixed-methods study. BMC Med Educ. 2016;16 (1):179. doi:10.1186/s12909-016-0704-3

24. Kaini BK. Interprofessional care and role of team leaders. $J$ Nepal Med Assoc. 2015;53(197):40-44. doi:10.31729/jnma.2705

25. Foronda C, MacWilliams B, McArthur E. Interprofessional communication in healthcare: an integrative review. Nurse Educ Pract. 2016;19:36-40. doi:10.1016/j.nepr.2016.04.005 covers a very wide range of areas and welcomes submissions from practitioners at all levels, from all over the world. The manuscript management system is completely online and includes a very quick and fair peer-review system. Visit http://www.dovepress.com/testimonials. php to read real quotes from published authors. 